\title{
大学院における長期インターンシップの取組と 今後の課題について
}

Approaches of Long-term Internship in a Graduate School and Subjects in the Future

\section{小栗 孝 明※ 1 \\ Takaaki OGURI}

Keywords : Long-term Internship, Industry-university Cooperation

キーワード：長期インターンシップ, 産学連携

\section{1.はじめに}

文部科学省では, 平成17年度から 6 年間に渡り, 大 学院を対象とした「産学連携による実践型人材育成事 業ー長期インターンシップ・プログラム開発 - (旧名 称：派遣型高度人材育成協同プラン)」を実施した。 本稿では, 当該事業の概要について説明するとともに, 特に工学系大学院において実施された取組事例を紹介 するものである.

\section{2. 事業の概要}

\section{1 背景}

文部科学省では, 平成 9 年に当時の通産省, 労働省 と共に「インターンシップの推進に当たっての基本的 考え方」を発表して以降，大学にお けるインターンシップの推進のため に様々な施策を講じてきた。

しかし, 近年, 科学技術人材育成の 大きな課題として, (1)自らの専門の 位置付けを社会活動全体の中で理解 し, (2)現実的課題の中から主体的に 問題設定を行い, それに取り組む能 力のある「高度専門人材の育成」が 急務であるとの認識が産業界及び学 会を中心に高まっており，また，政 府内に掠いても, 産学が協同で, 企 業の現場を活用しつつ高度専門人材 育成を行う「質」の高い新たな長期 派遣型（約 $3 \sim 6$ ケ月程度）の人材 育成体系の創設の必要が提起されて いた。

これらの要求に対応するため, こ れまでの主として就業体験や職業意
識の形成を目的としたインターンシップとは峻別し， 産学が人材育成・活用に関して建設的に協力しあう体 制を構築することにより, 社会の抱える諸課題や産業 界の取組を理解し, 知識基盤社会を多様に支える高度 で知的な素養のある人材を育成する，これまでにない 新たなコンセプトのインターンシップの開発を目的と した事業として,「産学連携による実践型人材育成事業 一長期インターンシップ・プログラム開発一」を創設 し, 平成17年度より 6 年間に渡り実施したものである (図 1 ).

\section{2 事業の推進}

（1）公募及び選定

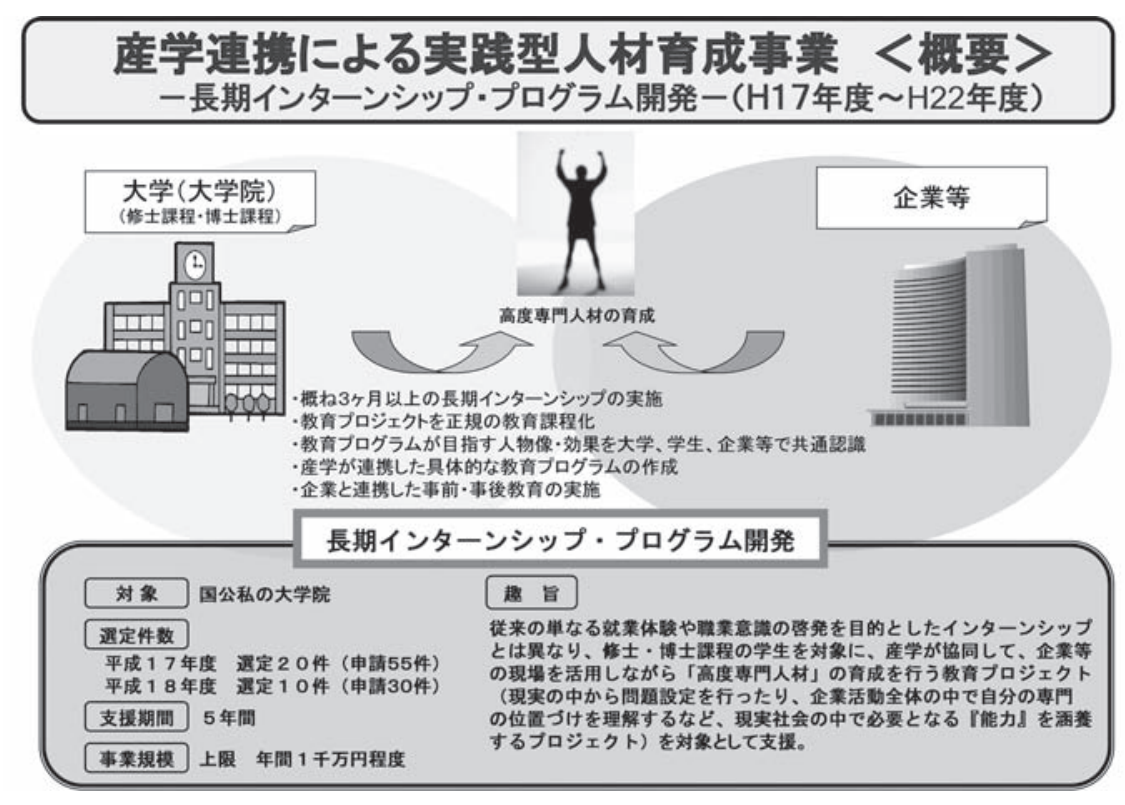

図 1 産学連携による実践型人材育成事業－長期インターンシップ・プログラム 開発一について 
本事業は補助対象期間を 5 年間とし, 平成17年度と 平成18年度にそれぞれ公募を実施した。

平成17年度は修士課程（博士（前期）課程を含む, 以下同じ）を中心とした取組を公募の対象とし，55件 の申請から有識者や専門家で構成される「産学連携高 度人材育成推進委員会 (以下, 委員会)」による審査を 経て，20件が採択された。

次いで平成18年度には博士課程（博士（後期）課程 を含む, 以下同じ）にも対象を拡大して公募を実施し， 30件の申請から委員会による審査を経て，10件が採択 された。

(2) 中間評価

事業開始から 3 年目に当たる平成 19 年度及び平成 20 年度に，委員会による事業の中間評価を実施した。評 価は, (1)各大学から提出された調書に基づく書面審査, (2)関係者からのヒアリングを実施のうえで, (3)必要と 判断された大学に対して現地調查を実施した。

中間評価では, 多くの大学が「一層の努力が必要と 判断される」「当初目的を達成することは難しいと思わ れる」と評価され, 委員会から各大学に対して, 今後 の取組に対する要望や助言が行われた.

(3) 最終評価

最終評価は平成 17 年度・18年度採択分をまとめて平 成23年度に実施し，(1)各大学から提出された調書に基 づく書面審查，(2)関係者からのヒアリングを実施のう えで決定された. 中間評価以降の各大学の努力により, 大半の大学が「所期の計画と同等の取組が行われた」 と評価された，また，少数ではあるが，最高評価であ る「所期の計画を超えた取組が行われた」が付けられ た取組を実施した大学もあり, 本事業の所期の目的は 達成することができたと言える。

\section{3. 具体的な取組事例}

ここでは, 事業に採択された工学系大学院による取 組のうち, 代表的な取組を紹介する。

\section{1 山形大学「産学連携による研究開発人材育成プ} ログラム」(平成17～21年度）（図 2)

本プログラムは, 製品提案型企業への変貌が生き残 りのための重要な課題になっている. 地域のものづく り企業との産学連携研究開発を活用して人材育成を図 ろうとする試みであり, 既に大学が共同研究を進めて いる企業との信頼関係をもとに, 研究開発人材育成プ ログラムを具体化させたものである.

本プログラム実施のため, 企業・大学教職員・外部 の有識者による連携組織であるプログラム推進委員会 を設置し，本プロジェクトの成果目標・教育目的・教 育手法等を定め, 参加企業と大学との間の認識を共有 することで，共同で学生を教育していく体制を確立す るとともに, 事業の推進にあたり生じた諸問題の解決 に当たっている.
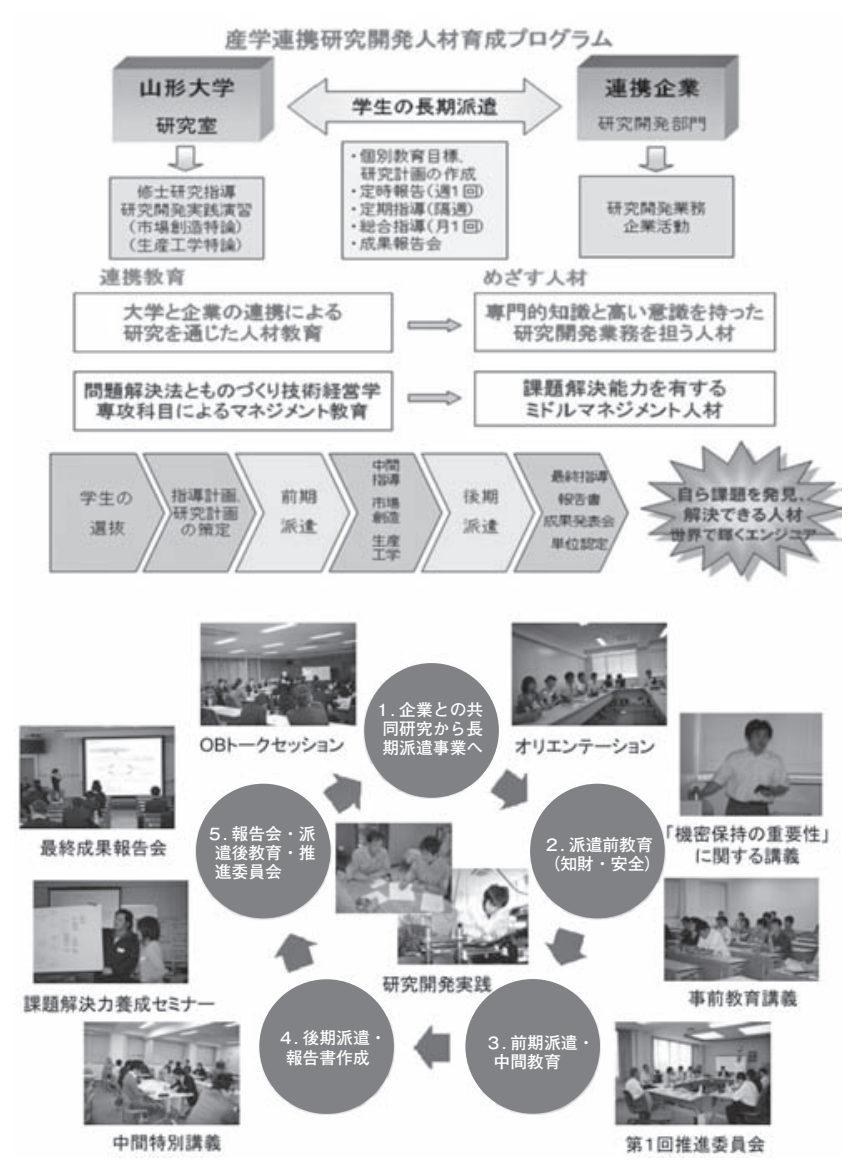

図 2 山形大学「産学連携による研究開発人材育成プログ ラム」

インターンシップは前期派遣・後期派遣それぞれ 2 ケ月間の合計 4 ケ月間を基本とし, 事前・事後教育に 加えて前期派遣と後期派遣の間に中間指導が実施され ている点が特徵である。中間指導では, 前期派遣期間 の研究成果・教育的成果を振り返り, 中間報告書を作 成するとともに, 企業・学生・教員の間で前期派遣の 目標達成度や研究についての検証を行い, 後期派遣の 計画修正等を実施するほか, 課題発見能力・解決力の 育成を図るための特別講義を実施することにより，後 期派遣がより充実したものとして実施されるよう工夫 している.

最終評価においては, 共同研究テーマと修士論文テ ーマのマッチングやカリキュラムの工夫により, 大学・ 企業双方に効果がある施策を取り入れたことにより, 毎年多くの実施実績を創出した点や, 補助期間終了後 も自立して事業を継続できる筋道を付けた点が評価さ れた。

3.2 豊橋技術科学大学「社会環境即応型リーダー技 術者育成プランーMOT指向生産システム技術 科学教育によるリーダー人材の養成一」(平成 18〜22年度）（図 3）

豊橋技術科学大学では, 学部段階において卒業研究 後に実務訓練として，2 月月間のインターンシップを 必修として実施しているが, 従来の実務訓練が就労 


\section{らせん型教育 (基礎 $\Leftrightarrow$ 専門, 理論 $\Leftrightarrow$ 実践)における本プロジェクトの位置付け}

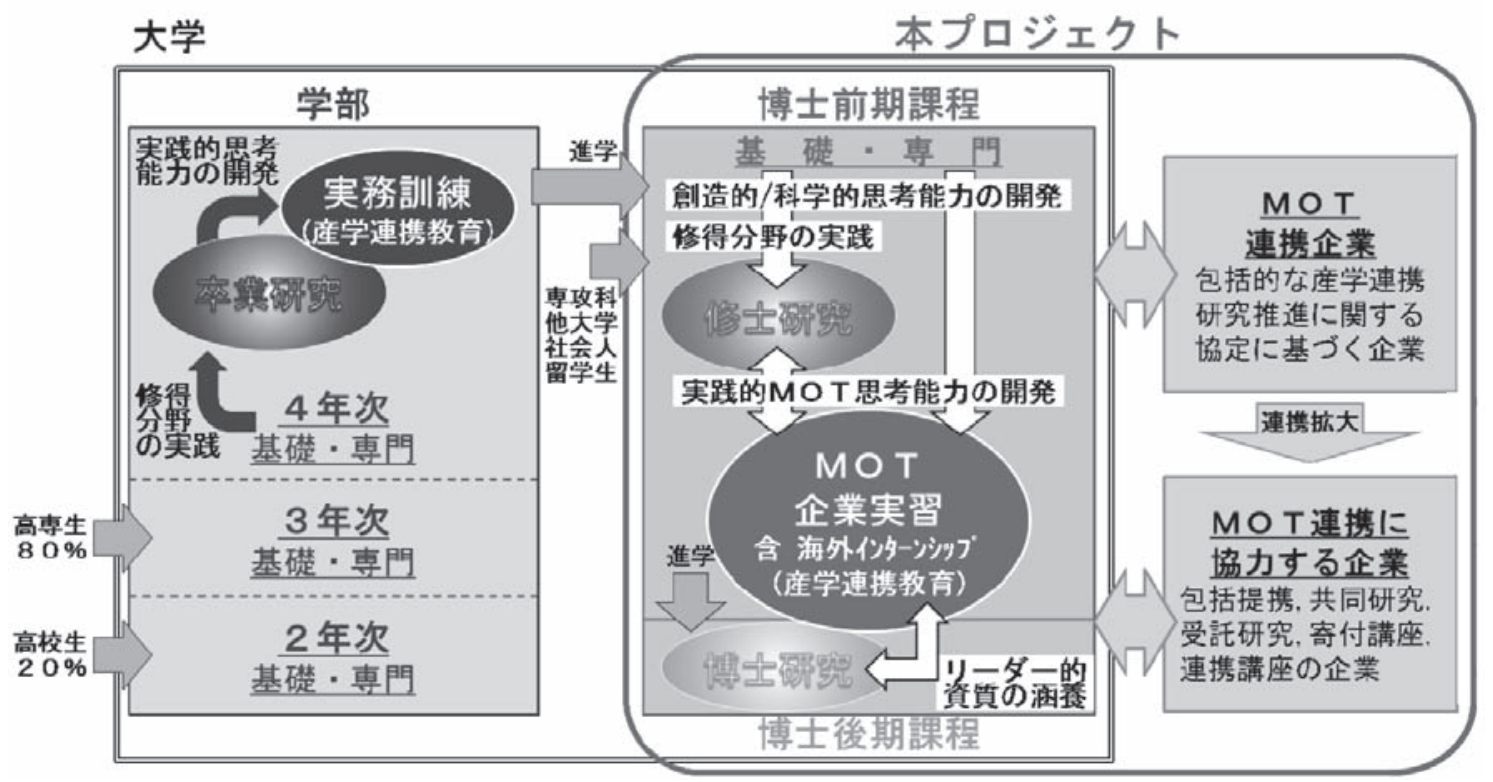

図 3 豊橋技術科学大学「社会環境即応型リーダー技術者育成プランーMOT指向生産システム 技術科学教育によるリーダー人材の養成 -」

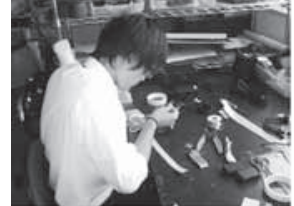

研究開発ベンチャー企業での実習風景

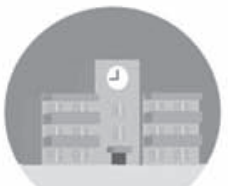

横浜国立大学

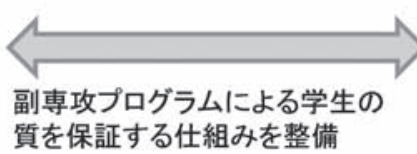

質を保証する仕組みを整備

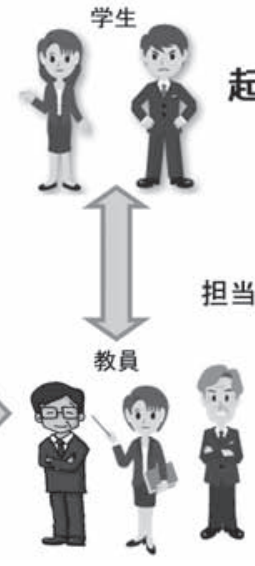

起業家型人材の育成

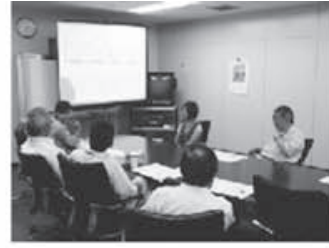

担当教員による手厚いフォローアップ

企莱トップを前に成果報告

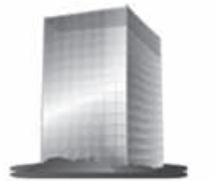

積極的な受入企業開拓と 課題設定、解決提案の取組み

図 4 横浜国立大学「横浜発研究開発ベンチャーインターンシップ」

体験を通じての実践指向型の技術者養成であるのに 対し，本プログラムでは，知的基盤社会の現状．市 場性や財務リスクを的確に捉えることのできるMOT (Management of Technology) 能力に優れた社会環境 即応型のリーダー的技術者を養成することを目指して いる点に特色がある.

また，企業との連携体制の構築に当たって，企業と の間で産学連携に関する協定を締結し，包括的な産学 連携による共同研究及び委託研究に長期インターンシ ップ・プログラムを組み込むことにより，実際に進行 している応用研究・製品開発（産側の実践力）の観点 と, それに対応する基礎的研究（学側の実践力と技術 科学力）の観点を融合させた研究開発・交流を行い, 実践的教育が実行できる連携体制を取っている.
本体制により，企業開発現場に㧍ける専門的開発研 究とMOT教育を実施することにより，社会環境，市 場性と財務リスクを的確に捉えることのできる問題発 掘能力とアイデア創成力に優れたリーダー型技術者の 養成を行っている.

最終評価においては，MOT教育を施す中で企業側 の機密内容まで踏み込んだインターンシップを実施す るという仕組みを構築した点や，就職した修了者に対 する追跡調查により，事業の分析・評価を試みている 点等が評価された。

\section{3 横浜国立大学「横浜発研究開発ベンチャー イ} ンターンシップ」（平成17～21年度）（図 4)

本プログラムは, 主として研究開発型ベンチャー企 業を対象とし, 事業体験のほか企業が抱える研究開発 
課題などに対して, 学生が研究室などで培った知識・ 技術を持ってインターンシップに取り組むことを特徴 としている.

取組は横浜国立大学ベンチャー・ビジネス・ラボラ トリー（以下横浜国立大学 VBL）の推進する「起業家 型人材育成モデル事業」の柱として位置付けられてお り, 大学院共通科目の一つとして実施され，修了者に は「起業家人材養成教育プログラム認定証」が授与さ れるとともに，副専攻プログラム「ベンチャー・ビジ ネス」の修得が成績履修台帳に特記される仕組みとな っている.

本プログラムの実施にあたり横浜国立大学 VBLで は応募学生との個人面談を複数回行い, 研究内容や専 門性, 現在の興味, 将来の展望, 受入企業への希望等 をヒアリングし, 各学生にあった受入企業を検討し, 学生, 受入企業, 担当スタッフの面談を経て受入企業 を決定している.

学生は受入企業において, 単に企業の用意したプロ グラムをこなすだけではなく, 与えられた課題の解決 に向けて自ら考え工夫して実習を進め, VBL担当ス夕 ッフの中間フォローも踏まえつつ, 資料の作成やプレ ゼンテーションの実施等を行った。

最終評価では, 本来大学の不得手とするべンチャー 育成という領域の人材育成について，「ベンチャー型 インターンシップ」という新しい領域でモデルケース を確立した点や, 毎年 20 人規模の実施をコンスタント に行い, 副専攻「ベンチャー・ビジネス」を授与する 「派遣のモデル」を確立した点等が評価された.

\section{4. 長期インターンシップの課題}

本事業は，工学系の分野以外の様々な分野でも実施 され, 今回紹介した取組以外にも, 海外での長期イン ターンシップの取組等, 多様かつ特徵的な取組が展開 された．しかしながら，本事業を通して見えてきた共 通的な課題として,

(1)産学が連携した取組について，その重要性や意義
を理解し推進する教員はいまだ少数にとどまってお り, 大学としてのリーダーシップの発揮と, より多くの 教員の理解・協力が必要であること, (2)テーマの設定 や派遣のパターン・時期と, 大学院のカリキュラムと の十分な調整が必要であること, (3)長期インターンシ ップの目的を十分理解し, その重要性を深く認識でき るよう大学と受入企業との間で十分な意見交換が必要 であること，また特に，(4)海外インターンシップを実 施する場合は, 教育プログラムに関する双方の理解と 相互信頼, 十分な準備期間及びリスクマネジメント体 制の確立が必須要件であること等が明らかとなった。

どの分野においても, 上記の点について十分に対応 するためには，学内でより強力な体制を整備すること が必要である。本事業の採択大学においては, これら の課題について対応しつつ, それぞれの取組をさらに 発展させていくとともに, その優れた取組が長期イン ターンシップの導入を図ろうとしている大学に対する ひとつの指針となることを期待したい.

\section{5.おわりに}

本稿で紹介した事業による取組事例は, 他の大学に おける取組の参考となることが期待されている。 今 後, 各大学において長期インターンシップを導入する にあたり本事業による取組がその参考となれば幸いで ある。

なお，各大学の具体的な取組内容及び評価について は, 下記URLを参照されたい.

http ://www.mext.go.jp/a_menu/koutou/sangaku/ index.htm

\section{著 者 紹 介}

小栗 孝明

文部科学省高等教育局専門教育課 教育振興係長 